\title{
EFFECTS OF ELEVATED SEAWATER CO2 CONCENTRATION ON THE MEIOFAUNA
}

\author{
Haruko Kurihara \\ Institute for East China Sea Research, Nagasaki University, 1551-7 Tairamachi, Nagasaki, 851-2213, Japan., \\ harukoku@e-mail.jp \\ Atsushi Ishimatsu \\ Institute for East China Sea Research, Nagasaki University, 1551-7 Tairamachi, Nagasaki, 851-2213, Japan. \\ Yoshihisa Shirayama \\ Seto Marine Biological Laboratory, Kyoto University, 459 Shirahama, Nishimuro, Wakayama, 649-2211, Japan.
}

Follow this and additional works at: https://jmstt.ntou.edu.tw/journal

Part of the Aquaculture and Fisheries Commons

\section{Recommended Citation}

Kurihara, Haruko; Ishimatsu, Atsushi; and Shirayama, Yoshihisa (2007) "EFFECTS OF ELEVATED SEAWATER CO2 CONCENTRATION ON THE MEIOFAUNA," Journal of Marine Science and Technology. Vol. 15: Iss. 5, Article 2. DOI: $10.51400 / 2709-6998.2054$

Available at: https://jmstt.ntou.edu.tw/journal/vol15/iss5/2

This Research Article is brought to you for free and open access by Journal of Marine Science and Technology. It has been accepted for inclusion in Journal of Marine Science and Technology by an authorized editor of Journal of Marine Science and Technology. 


\section{EFFECTS OF ELEVATED SEAWATER CO2 CONCENTRATION ON THE MEIOFAUNA}

Acknowledgements

We gratefully acknowledge Mr. K. Okita and Mr. Y. Yamamoto for their help in sampling the sediments. We are thankful to Mr. M. Oota, Mr. K. Tsugoshi and Mr. T. Yamamoto for helping set up the microcosms. We thank Dr. G. Itani for advice on statistical analysis. 


\title{
EFFECTS OF ELEVATED SEAWATER $\mathrm{CO}_{2}$ CONCENTRATION ON THE MEIOFAUNA
}

\author{
Haruko Kurihara*, Atsushi Ishimatsu* and Yoshihisa Shirayama**
}

Key words: $\mathrm{CO}_{2}$, decreased $\mathrm{pH}$, nematoda, harpacticoid copepoda.

\begin{abstract}
An increase in atmospheric $\mathrm{CO}_{2}$ concentration leads to a rise in $\mathrm{CO}_{2}$ concentrations and a decrease in $\mathrm{pH}$ of the ocean surface water due to continuous gas exchange between air and seawater, which may have serious impacts on neritic marine organisms. In this study, we assessed the impacts of elevated $\mathrm{CO}_{2}$ concentrations on meiobenthic organisms by exposing them to seawater equilibrated with air (control: $\mathrm{CO}_{2}$ concentration $\left.380 \mathrm{ppm}\right)$ or $\mathrm{CO}_{2}$-enriched air $(2,000 \mathrm{ppm}$ higher than control, $\mathrm{CO}_{2}$ concentration predicted by the year 2300) for 56 days in microcosms. We observed no significant differences in the abundance of total meiofauna, nematodes, harpacticoid copepods (including adults and copepodites) and nauplii by the end of the experiment. These results suggest that the projected atmospheric $\mathrm{CO}_{2}$ concentration in the year 2300 does not have acute effects on the meiofauna. However, further studies are needed to evaluate longerterm effects of elevated $\mathrm{CO}_{2}$ on meiobenthic organisms.
\end{abstract}

\section{INTRODUCTION}

The atmospheric concentration of carbon dioxide $\left(\mathrm{CO}_{2}\right)$ has increased from the pre-industrial level of 280 parts per million (ppm) to $380 \mathrm{ppm}$ as a result of anthropogenic $\mathrm{CO}_{2}$ emission associated with industrialization [11]. The resulting global warming has already impacted terrestrial and marine ecosystems [18, 24], and a further rise in temperature is predicted to intensify sea surface stratification and drastically alter marine ecosystem $[1,19]$. In addition to the indirect effects of $\mathrm{CO}_{2}$ due to global warming, recent studies have revealed direct effects of $\mathrm{CO}_{2}$ on terrestrial ecosystems, and have predicted serious impacts on interactions between plants and insects $[4,7]$.

Due to continuous gas exchange between air and seawater [22], an increase in atmospheric $\mathrm{CO}_{2}$ concentrations will raise $\mathrm{CO}_{2}$ concentrations at the ocean

Author for Correspondence: Haruko Kurihara.

E-mail:harukoku@e-mail.jp.

*Institute for East China Sea Research, Nagasaki University, 1551-7 Tairamachi, Nagasaki, 851-2213, Japan.

**Seto Marine Biological Laboratory, Kyoto University, 459 Shirahama, Nishimuro, Wakayama, 649-2211, Japan. surface, and decrease seawater $\mathrm{pH}$ through the dissociation of carbonic acid formed by the increased $\mathrm{CO}_{2}$ [5]. The atmospheric $\mathrm{CO}_{2}$ concentration is predicted to increase to above $2,100 \mathrm{ppm}$, and thereby reducing the $\mathrm{pH}$ of the ocean surface water by about 0.77 units by the year 2300 [5]. These chemical changes in seawater likely have significant impacts on neritic marine organisms.

Most published studies on the effects of $\mathrm{CO}_{2}$ on marine organisms have focused on calcification responses to elevated seawater $\mathrm{CO}_{2}$ concentration (for review, see Supporting Online Material of Feely et al. [8]). Riebesell et al. [17] also demonstrated that the growth rate of marine diatoms Thalassiosira punctigera and Rhizosolena cf. alata increased with $\mathrm{CO}_{2}$ concentration. These previous studies mostly employed short-term exposure protocols and only very few evaluated long-term effects of increased $\mathrm{CO}_{2}$ on marine organisms. Recently Michaelidis et al. [15] reported that the growth and metabolic rates of the marine mussels Mytilus galloprovincialis decreased when exposed to $\mathrm{CO}_{2}$-acidified seawater ( $\mathrm{pH} 7.3$ ) for 3 months. Shirayama and Thornton [21] demonstrated that growth of sea urchins Hemicentrotus pulcherrimus and Echinometra mathaei was suppressed by 6-month exposure to seawater equilibrated with $\mathrm{CO}_{2}$-enriched air $(580 \mathrm{ppm})$. It is therefore conceivable that long-term exposure of marine organisms to elevated $\mathrm{CO}_{2}$ concentration seawater for several generation could potentially result in decreases of population size.

In the present study, we incubated meiobenthic communities under elevated $\mathrm{CO}_{2}$ conditions $(2,000 \mathrm{ppm}$ above ambient) for 56 days to investigate changes in abundance and biomass of nematodes and harpacticoid copepods. Meiofauna is suitable for studying long-term effects because of its short generation time, rapid growth, and high abundance in a small area. In addition, despite their small size, meiobenthic faunas are important in the energy flow of marine benthic ecosystems [9]. Here, we focused on nematodes and harpacticoid copepods because they usually account for more than $90 \%$ of the total meiofauna in mud environments [10], and owing to their confinement in the oxidized layers of sediment (usually in the top $1 \mathrm{~cm},[6]$ ), they may be more suscep- 
tible to the direct and indirect effects of seawater $\mathrm{CO}_{2}$. We also investigated the effects on nauplius larvae, because the early developmental stages are thought to be particularly sensitive to environmental changes [14].

\section{MATERIAL AND METHODS}

Sediments were sampled with a Smith McIntyre grab from the seafloor (approximately $10 \mathrm{~m}$ in depth) of the Tanabe Bay, in the Kii Peninsula, Japan $\left(33^{\circ}\right.$ $42.2^{\prime} \mathrm{N}, 135^{\circ} 22.9^{\prime} \mathrm{E}$ ) on 30 January 2001 . The top $5 \mathrm{~cm}$ layer was used for the experiment.

The experiment was conducted for two months (from 1 February to 29 March, 2001) in an indoor microcosm system. The sediments were homogenized by stirring and were placed in six microcosms (capacity $30 \mathrm{~L}$ ) to a depth of $7 \mathrm{~cm}$ and covered with seawater. Microcosms were placed in a flow-through container into which coastal seawater was pumped continuously. Air was supplied at a rate of $500 \mathrm{ml} \mathrm{min}^{-1}$ to the water in three microcosms, $\left(\mathrm{CO}_{2}\right.$ concentration $360 \mathrm{ppm}$, control groups) whereas the water in the other three microcosms were aerated with $\mathrm{CO}_{2}$-enriched air $\left(\mathrm{CO}_{2}\right.$ concentration 2,000 ppm higher than the air, $\mathrm{CO}_{2}$ groups). The flow rates of air $\left(500 \mathrm{ml} \mathrm{min}^{-1}\right)$ and $\mathrm{CO}_{2}(1 \mathrm{ml} \mathrm{min}$ ${ }^{1}$ ) were controlled using flow meters (Kofloc). The pH and temperature of water in each microcosm was measured daily using a pH meter (Horiba, D-25). No food was supplied. The entire volume of seawater in each microcosm was renewed once a week throughout the experiment. The photoperiod was set to 14L:10D.

To monitor changes in the meibenthic community, sediment was sampled on days 0 (untreated cores), 7 , $14,21,28$, and 56. At each sampling, one sediment core (1-cm deep) was taken from each microcosm using a plastic syringe, the tip of which was cut off to make a cylinder $(2.0 \mathrm{~cm}$ internal diameter). Sediment samples were preserved in $5 \%$ borax-buffered formalin seawater. Rose Bengal was added to stain the meiofaunae. The samples were sieved through stainless steel sieves with mesh size of $500,250,125,63$, and $32 \mu \mathrm{m}$, and the number of meiofauna was counted under a dissecting microscope. The biomass of the meiofauna was calculated by using the standard ash-free dry weight per individual as reported by Shirayama [20]. Treatment effects were evaluated statistically using Student t-test and two-way ANOVA. Values are given as means \pm S.D.

\section{RESULTS}

\section{Temperature and pH}

During the experiment, seawater temperature of each microcosm varied between $13.0^{\circ} \mathrm{C}$ to $17.8^{\circ} \mathrm{C}$ (Figure 1). The difference in water temperature was less than $0.1^{\circ} \mathrm{C}$ between any two microcosms throughout the experiment. The average seawater $\mathrm{pH}$ values of the control and $\mathrm{CO}_{2}$ groups were $8.20 \pm 0.05$ and $7.40 \pm$ 0.07 , respectively (Figure 1 ).

\section{Effects on the abundance and biomass of meiofauma}

The abundance of total meiofauna was significantly lower in the $\mathrm{CO}_{2}$ groups than in the control of the same day only on day 7 (t-test, $p<0.05$, Figure 2). The total biomass fluctuated in both control and $\mathrm{CO}_{2}$ groups during the experiment (2-way ANOVA, $p<0.05$, Figure 2), but there was no difference between the two groups at any given day of observation throughout the experiment ( $t$-test, Figure 2).

The composition of meiobenthic community in this study consisted of nematodes $(67.8 \pm 7.5 \%)$, harpacticoid copepods $(24.4 \pm 4.4 \%)$, nauplii larvae $(4.3 \pm 2.7 \%)$, ostracods $(1.6 \pm 1.6 \%)$, turbellarians $(1.9$ $\pm 1.4 \%)$ and polychaeta $(0.1 \pm 0.3 \%)$. The foraminiferans were excluded from our analysis because of their fragile nature.

The abundance and the biomass of the two dominant taxa, nematodes and copepods (including adults and copepodites), were further investigated to examine possible changes in meiofauna composition. The abundance of nematodes varied significantly with time in both control and $\mathrm{CO}_{2}$ groups (2-way ANOVA, $p<0.05$, Figure 3), whereas there was no difference between the

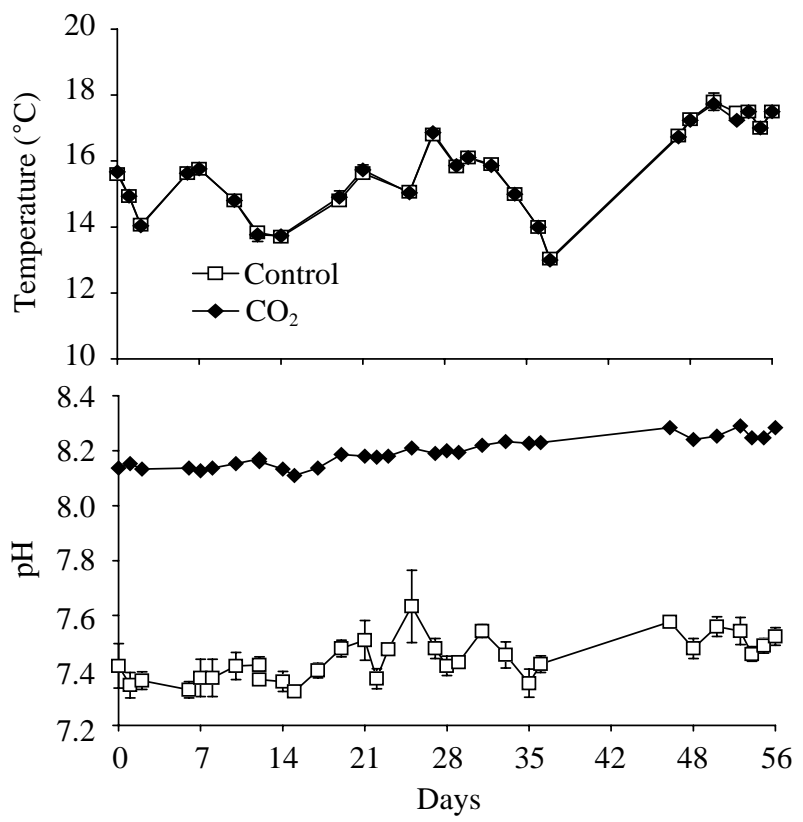

Fig. 1. Mean seawater temperature and $\mathrm{pH}$ of the control and $\mathrm{CO}_{2}$ microcosms during the experimental period. 

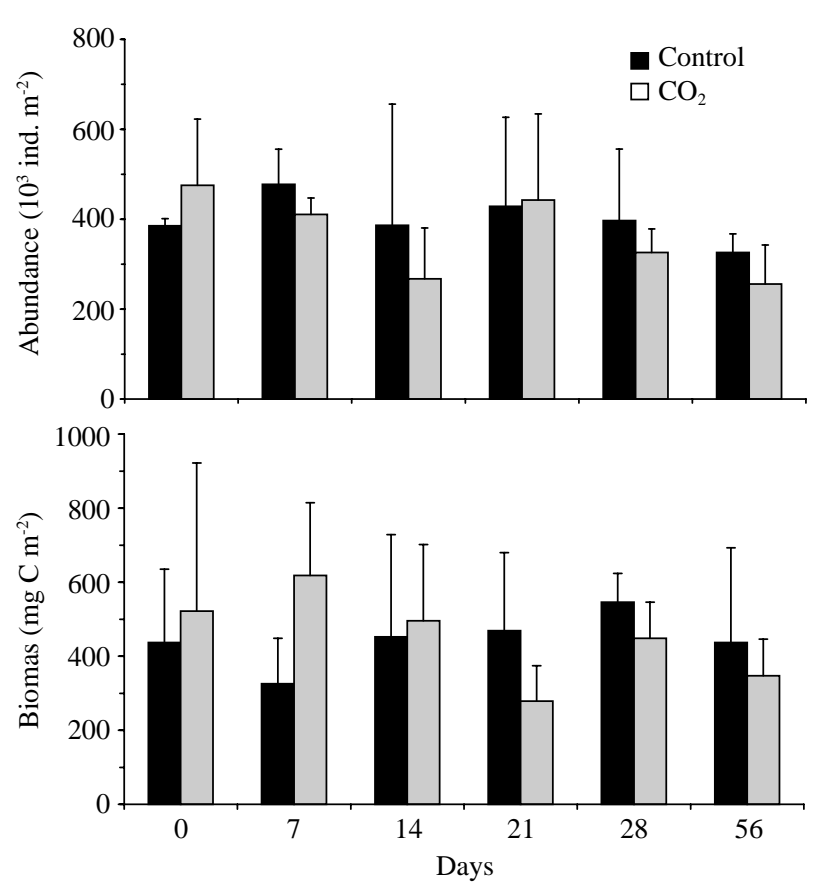

Fig. 2. Change in abundance and biomass of total meiofauna in control and $\mathrm{CO}_{2}$ groups from day 0 to day 56. Initial abundance of total meiofauna was $385 \times 10^{3} \pm\left(16 \times 10^{3}\right)$ ind. $\mathrm{m}^{-2}$ (control) and $475 \times 10^{3} \pm\left(147 \times 10^{3}\right)$ ind. $\mathrm{m}^{-2}\left(\mathrm{CO}_{2}\right.$ groups $)$. Initial biomass of total meiofauna was $437 \times 197 \mathrm{mgC} \mathrm{m}^{-2}$ (control) and $521 \pm 400 \mathrm{mgC} \mathrm{m}^{-2}\left(\mathrm{CO}_{2}\right.$ microcosms). Mean $\pm \mathrm{SD}$ of three replicate microcosms. * Significant difference between control and $\mathrm{CO}_{2}$ groups $(p<0.05, t$-test $)$.

two except on day 7 ( $t$-test, $p<0.05$, Figure 3 ). There was a decreasing tendency in nematode biomass in both groups (2-way ANOVA, $p<0.05$, Figure 4), although no significant difference was detected between the two groups at any given day of observation ( $t$-test, Figure 4).

No difference in the abundance of harpacticoid copepods was either detected throughout the experiment between the two groups ( $t$-test, Figure 3 ). On day 7 , the biomass of harpacticoid copepods in $\mathrm{CO}_{2}$ groups was significantly higher than control groups, whereas the reverse was true on day 21 ( $t$-test, $p<0.05$, Figure 4).

No difference in the abundance of harpacticoid nauplii was detected throughout the experiment between the two groups ( $t$-test, Figure 3 ). The abundance of other components of meiofauna, such as polychaetes, ostracods, and turbellarians, were also unaffected by $\mathrm{CO}_{2}$.

\section{Effects on the different sizes of meiofauna}

We analyzed the size structure of nematodes and harpacticoid copepods to evaluate the size dependency
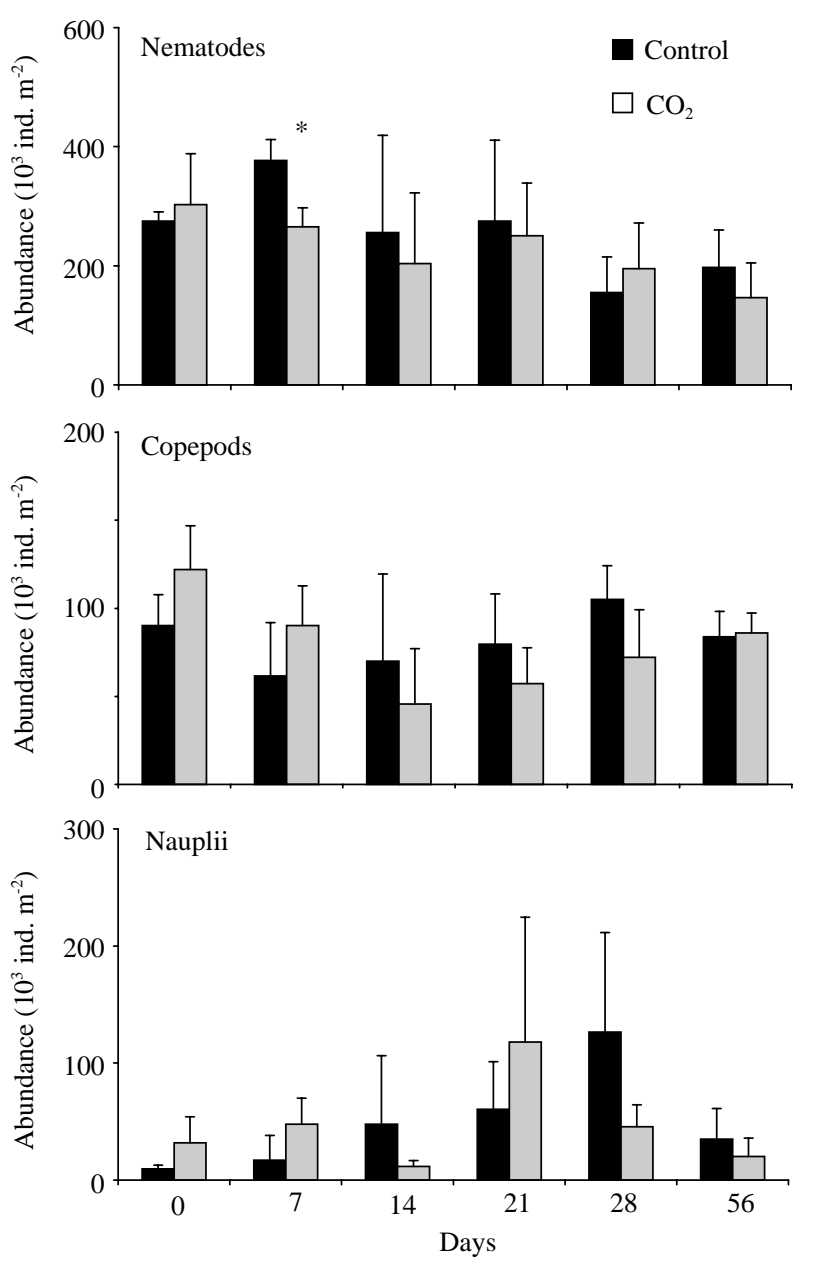

Fig. 3. Changes in the abundance of nematodes, harpacticoid copepods and nauplii in sediment in control and $\mathrm{CO}_{2}$ groups from day 0 to day 56. Initial abundance of nematodes was $274 \times 10^{3}$ $\pm\left(16 \times 10^{3}\right)$ ind. $\mathrm{m}^{-2}$, copepods was $90 \times 10^{3} \pm\left(18 \times 10^{3}\right)$ ind. $\mathrm{m}^{-2}$, and nauplii was $10 \times 10^{3} \pm\left(3 \times 10^{3}\right)$ ind. $\mathrm{m}^{-2}$ (control). Initial abundance of nematodes was $302 \times 10^{3} \pm\left(86 \times 10^{3}\right)$ ind. $\mathrm{m}^{-2}$, copepods was $122 \times 10^{3} \pm\left(25 \times 10^{3}\right)$ ind. $\mathrm{m}^{-2}$, and nauplii was $31 \times 10^{3} \pm\left(22 \times 10^{3}\right)$ ind. $\mathrm{m}^{-2}\left(\mathrm{CO}_{2}\right.$ groups $)$. Mean $\pm S D$ of three replicate microcosms. * Significant difference between control and $\mathrm{CO}_{2}$ groups $(p<0.05, t$-test $)$.

of $\mathrm{CO}_{2}$ tolerance. The most abundant sizes of nematodes and harpacticoid copepods were between 250 and $125 \mu \mathrm{m}$ (Figures 5, 6). For nematodes, there was a significant difference between treatments in the abundance of 250 - to $125 \mu \mathrm{m}$ size classes on day 7 ( $t$-test, $p$ $<0.05$, Figure 5c), but not in the other size classes (Figure 5). For harpacticoid copepods, no significant differences were observed between treatments in any size class throughout the experiment (Figure 6).

\section{DISCUSSION}

Our results suggest that atmospheric $\mathrm{CO}_{2}$ concen- 


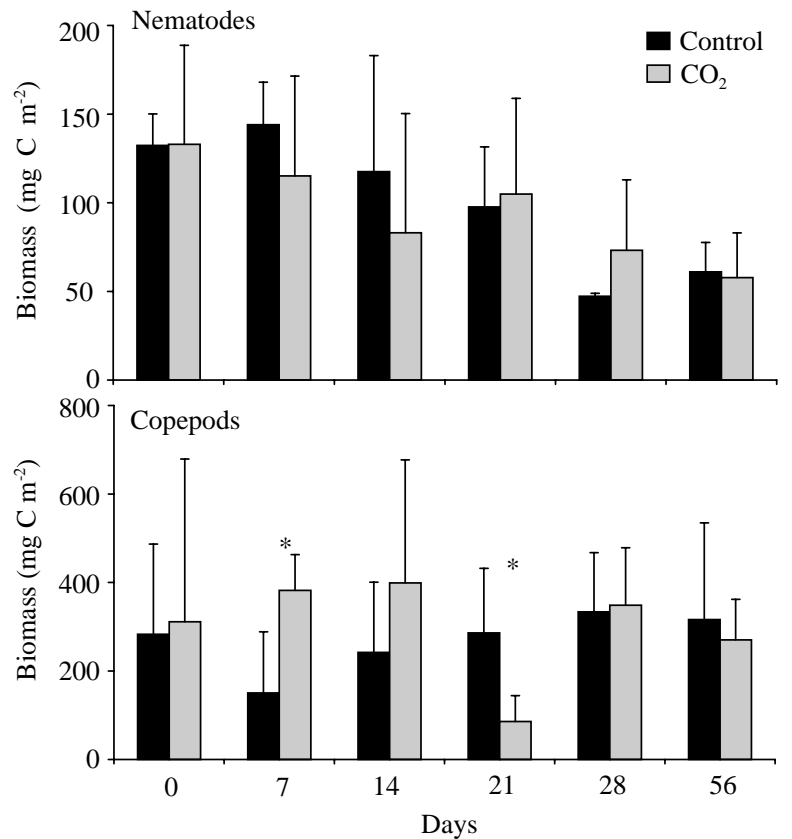

Fig. 4. Change in the biomass of nematodes and harpacticoid copepods in control and $\mathrm{CO}_{2}$ groups from day 0 to day 56. Initial abundance of nematodes was $132 \pm 17 \mathrm{mgC} \mathrm{m}^{-2}$ and copepods was $282 \pm 203 \mathrm{mgC} \mathrm{m}^{-2}$ (control). Initial abundance of nematode was $310 \pm 367 \mathrm{mgC} \mathrm{m}^{-2}$ and copepods was $133 \pm 55 \mathrm{mgC}$ $\mathrm{m}^{-2}$ (CO $\mathrm{CO}_{2}$ groups). Mean $\pm \mathrm{SD}$ of three replicate microcosms. * Significant difference between control and $\mathrm{CO}_{2}$ groups $(p<$ $0.05, t$-test).

tration projected by the year $2300(2,000 \mathrm{ppm}$ higher than the control) does not induce lethal effects on most meiofaunae, at least within 56 days. In contrast, Shirayama and Thornton [21] showed that increased mortality of sea urchins and a gastropod after 6 months, when they were exposed to only $200 \mathrm{ppm}$ above ambient or $580 \mathrm{ppm} \mathrm{CO}_{2}$. Similarly, we observed increased mortality of shrimps Palaemon pacificus exposed to $1,000 \mathrm{ppm} \mathrm{CO}_{2}$ for 30 weeks and to $2,000 \mathrm{ppm} \mathrm{CO}_{2}$ concentrations for 15 weeks (submitted). Thus, $\mathrm{CO}_{2}$ tolerance differs markedly among marine organisms. The apparent higher tolerance of the benthic meiofauna may be attributable to several factors. First, the sea urchins, gastropod and shrimps are epibenthos, exposing themselves to ambient seawater, whereas the organisms examined in the present study largely confine themselves in sedimentary mud. Because of larger fluctuations of $\mathrm{CO}_{2}$ concentration in pore water, species dwelling in sediments may be more tolerant to $\mathrm{CO}_{2}$ than pelagic organisms [16]. Second, calcified marine organisms such as snails, echinoderms and crustaceans are thought to be more sensitive to $\mathrm{CO}_{2}$ than other organisms due to the high sensitivity of $\mathrm{CO}_{2}$ effects on calcification mechanisms [8]. Specific difference in the response to elevated $\mathrm{CO}_{2}$ may change community
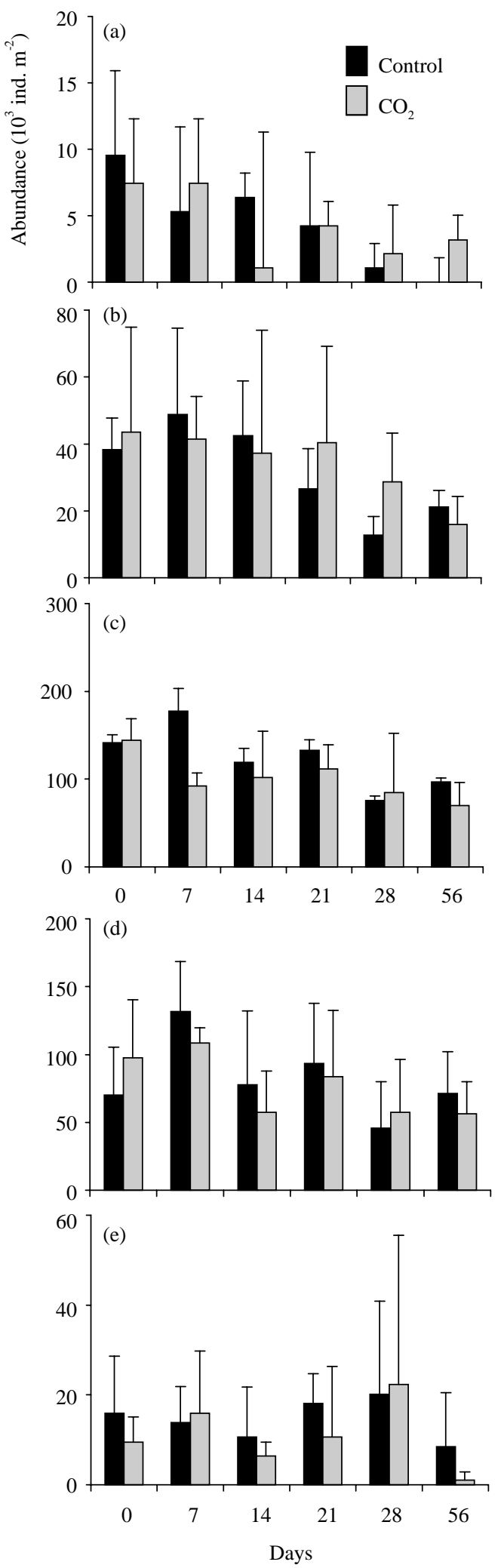

Fig. 5. Changes in the abundance of nematodes of different size classes: (a) $>500 \mu \mathrm{m}$, (b) 500-250 $\mu \mathrm{m}$, (c) 250-125 $\mu \mathrm{m}$ (d) $125-63 \mu \mathrm{m}$, and (e) 63-32 $\mu \mathrm{m}$ in control and $\mathrm{CO}_{2}$ groups from day 0 to day 56 . Mean \pm SD of three replicate microcosms. * Significant difference between control and $\mathrm{CO}_{2}$ groups $(p<0.05, t$-test $)$. 

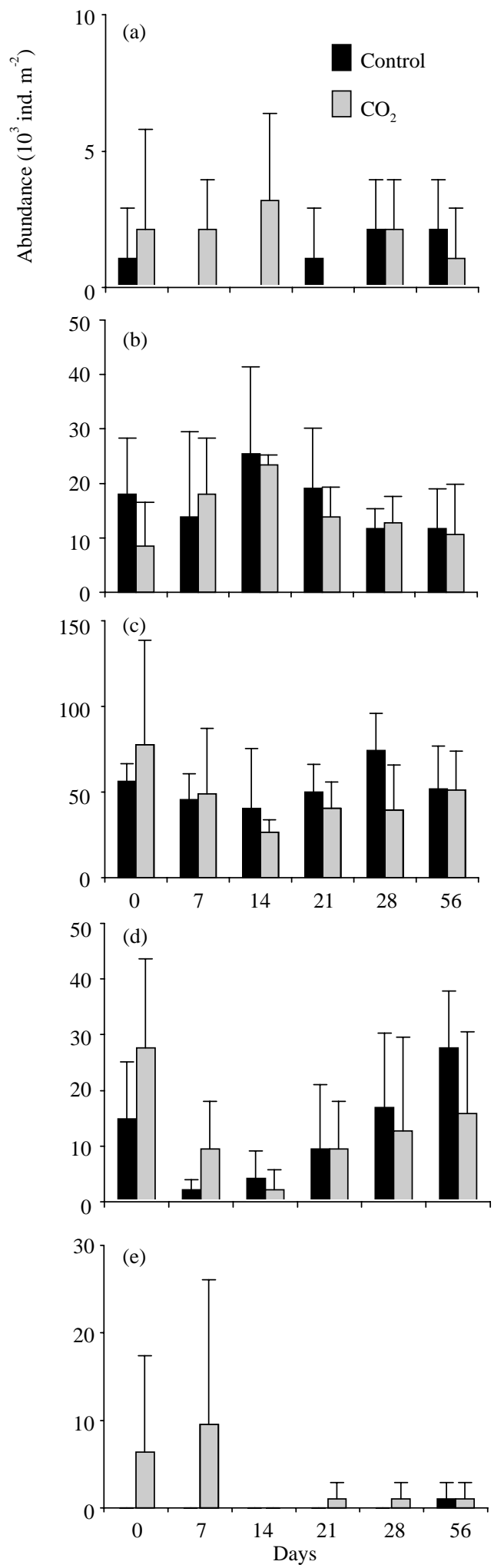

Fig. 6. Changes in the abundance of harpacticoid copepods of different size classes: (a) $>500 \mu \mathrm{m}$, (b) 500-250 $\mu \mathrm{m}$, (c) 250-125 $\mu \mathrm{m}$ (d) 125-63 $\mu \mathrm{m}$, and (e) 63-32 $\mu \mathrm{m}$ in control and $\mathrm{CO}_{2}$ groups from day 0 to day 56. Mean \pm SD of three replicate microcosms. * Significant difference between control and $\mathrm{CO}_{2}$ groups $(p<$ $0.05, t$-test). structure, and thereby have ecosystem-level consequences.

Even though meiobenthos are not lethally affected by elevated $\mathrm{CO}_{2}$, it is highly possible that raised $\mathrm{CO}_{2}$ have sub-lethal effects on reproduction, metabolism and growth rate. Michaelidis et al., [15] reported that long-term exposure ( 3 months) of the marine mussels to $\mathrm{CO}_{2}$-acidified seawater ( $\mathrm{pH}$ 7.3) resulted in a depression of respiration rate. Similarly, reduced growth rate and feeding activity under low $\mathrm{pH}$ were observed in clams and oysters $[2,3]$. When sea urchin eggs were reared under elevated $\mathrm{CO}_{2}$ levels, the fertilization rate of the eggs tended to decrease with increasing $\mathrm{CO}_{2}$ concentration [13]. In the present study, the abundance of small-sized nematodes (Figure 5e) and nauplius embryos (Figure 3 ) never disappeared throughout the experiment, although their abundance fluctuated in both control and $\mathrm{CO}_{2}$ microcosms. This suggest that may have been successful recruitments under elevated $\mathrm{CO}_{2}$ conditions, and therefore elevated $\mathrm{CO}_{2}$ had not impacted the reproduction of nematodes and harpacticoid copepods. However, it is possible that, there could have been a change in the species composition of nematodes or harpaticoid copepods, in spite of no observed change in the abundance or biomass of meiofauna in the elevated microcosms. Indeed, Takeuchi et al. [23] demonstrated in $\mathrm{CO}_{2}$ tolerance between marine nematode species. Analyses of nematodes and harpacticoids to a lower taxonomic level are needed to more closely evaluate impacts of raised $\mathrm{CO}_{2}$ on these meiofaunal taxa.

Investigating biological impacts of elevated $\mathrm{CO}_{2}$ is of importance in the context of understanding environmental impacts of not only ocean acidification due to increasing atmospheric $\mathrm{CO}_{2}$, but also of potential seepage from sub-seabed geological $\mathrm{CO}_{2}$ storage, for which no scientific information is currently available [12]. Biological impacts should differ depending on the extent (from geologically localized to spatially dispersed), duration (slow gradual to sudden intermittent), the magnitude of $\mathrm{CO}_{2}$ flux leaked, and the phase of $\mathrm{CO}_{2}$ (supercritical, liquid or gas), let alone the local fauna and flora of seepage sites. However, endobenthic organisms may well be subjected to much higher $\mathrm{CO}_{2}$ concentrations than the projected maximum concentrations of atmospheric $\mathrm{CO}_{2}$. Appropriate experimental protocols must be employed to evaluate the risk of potential seepage from sea-bed geological storage, because the expected hazards are distinctly different from the impact of $\mathrm{CO}_{2}$ injection into mid-water depths [12].

In conclusion, the results demonstrated that the increased seawater $\mathrm{CO}_{2}$ concentration used in the present study does not have acute impacts on the abundance and biomass of the meiofauna. Yet, it is possible that the meiofauna is sublethally affected when exposed to raised 
$\mathrm{CO}_{2}$ concentration for longer durations and that the meiobenthic community structure changes due to differences in $\mathrm{CO}_{2}$ tolerance among species. Further studies are needed to understand the future impacts of increasing atmospheric $\mathrm{CO}_{2}$ on the marine ecosystem.

\section{ACKNOWLEDGEMNT}

We gratefully acknowledge Mr. K. Okita and Mr. Y. Yamamoto for their help in sampling the sediments. We are thankful to Mr. M. Oota, Mr. K. Tsugoshi and Mr. T. Yamamoto for helping set up the microcosms. We thank Dr. G. Itani for advice on statistical analysis.

\section{REFERENCES}

1. Arrigo, K.R., Robinson, D.H., Worthen, D.L., Dunbar, R.B., DiTullio, G.R., VanWoert, M., and Lizotte, M.P., "Phytoplankton Community Structure and the Drawdown of Nutrients and $\mathrm{CO}_{2}$ in the Southern Ocean," Science, Vol. 283, pp. 365-367 (1999).

2. Bamber, R.N., "The Effects of Acidic Seawater on Young Carpet-Shell Clams Venerupis Decussata (L.) (Mollusca: Veneracea)," Journal of Experimental Marine Biology and Ecology, Vol. 108, pp. 241-260 (1987).

3. Bamber, R.N., "The Effects of Acidic Seawater on Three Species of Lamellibranch Mollusk," Journal of Experimental Marine Biology and Ecology, Vol. 143, pp. 181191 (1990).

4. Bezemer, T.M. and Jones, T.H. "Plant-Insect Herbivore Interactions in Elevated Atmospheric $\mathrm{CO}_{2}$ : Quantitative Analyses and Guild Effects," Oikos, Vol. 82, pp. 212-222 (1998).

5. Caldeira, K. and Wickett, M.E., "Anthropogenic Carbon and Ocean pH," Nature, Vol. 425, pp. 365 (2003).

6. Coull, B.C. and Bell, S.S., "Perspectives of Marine Meiofauna Ecology," In Livingstone, R. J. (Eds), Ecological Processes in Coastal and Marine Systems, Plenum Publishing Corporation, New York, pp. 189-216 (1979).

7. Coviella, C.E. and Trumble, J.T., "Effects of Elevated Atmospheric Carbon Dioxide on Insect-Plant Interactions," Conservation Biology, Vol. 13, No. 4, pp. 700-712 (1999).

8. Feely, R.A., Sabine, C.L., Lee, K., Berelson, W. Kleypas, J., Fabry, V.J., and Millero, F.J., "Impact of Anthropogenic $\mathrm{CO}_{2}$ on the $\mathrm{CaCO}_{3}$ System in the Oceans," Science, Vol. 294, pp. 362-366 (2004).

9. Gerlach, S.A., "On the Importance of Marine Meiofauna for Benthos Communities," Oecologia, Vol. 6, pp. 179190 (1971)

10. Giere, O., "The Impact of Oil Pollution on Intertidal Meiofauna. Field Studies after the La Coruna-Spill, May 1976," Les Cahiers de Biologie Marine, Vol. 20, pp. 231-251 (1979).

11. Houghton, J.T., Ding, Y., Griggs, D.J., Noguer van der Liden, M.P.J., Dai, X., Maskell, K., and Johnson, C.A.,
Climate Change 2001: The science of climate change, Cambridge Cambridge University (2001).

12. IPCC, Carbon Dioxide Capture and Storage, Cambridge Cambridge University (2005).

13. Kurihara, H. and Shirayama, Y., "Effects of Increased Atmospheric $\mathrm{CO}_{2}$ on Sea Urchin Early Development," Marine Ecology Progress Series, Vol. 274, pp. 161-169 (2004).

14. Kurihara, H., Shimode, S., and Shirayama, Y., "Effects of Raised $\mathrm{CO}_{2}$ Concentration on the Egg Production Rate and Early Development of Two Marine Copepods (Acartia Steueri and Acartia Erythraea)," Marine Pollution Bulletin, Vol. 49, pp. $721-727$ (2004).

15. Micahelidis, B., Ouzounis, C., Paleras, A., and Pörtner, H.O., "Effects of Long-Term Moderate Hypercapnia on Acid-Base Balance and Growth Rate in Marine Mussels Mytilus Galloprovincialis," Marine Ecology Progress Series, Vol. 293, pp. 109-118 (2005).

16. Pörtner, H.O., Langenbuch, M., and Reipschläger, A., "Biological Impact of Elevated Ocean $\mathrm{CO}_{2}$ Concentrations: Lesson from Animal Physiology and Earth History," Journal of Oceanography, Vol. 60, pp. 705-718 (2004).

17. Riebesell, U., Wolf-Gladrow, D.A., and Smetacek, V., "Carbon Dioxide Limitation of Marine Phytoplankton Growth Rates," Nature, Vol. 361, pp. 249-251 (1993).

18. Root, T.L., Price, J.T., Hall, K.R., Schneider, S.H., Rosenzweig, C., and Pounds, J.A., "Fingerprints of Global Warming on Wild Animals and Plants," Nature, Vol. 421, pp. 57-60 (2003).

19. Sarmiento, J.L., Hughes, T.M.C., Stouffer, R.J., and Manabe, S., "Simulated Response of the Ocean Carbon Cycle to Anthropogenic Climate Warming," Nature, Vol. 393, pp. 245-248 (1998).

20. Shirayama, Y., "Size Structure of Deep-Sea Meio- and Macrobenthos in the Western Pacific," Internationale Revue der Gesamten Hydrobiologie, Vol. 68, No. 6, pp. 799-810 (1983).

21. Shirayama, Y. and Thornton, H., "Effect of Increased Atmospheric $\mathrm{CO}_{2}$ on Shallow Water Marine Benthos," Journal of Geophysical Research, Vol. 110, C09S08 (2005).

22. Takahashi, T., Feely, R.A., Weiss, R.F., Wanninkhof, R. H., Chipman, D.W., Sutherland, S.C., and Takahashi, T. T., "Global Air-Sea Flux of $\mathrm{CO}_{2}$ : An Estimated Based on Measurements of Sea-Air $\mathrm{pCO}_{2}$ Difference," Proceedings of the National Academy of Sciences USA, Vol. 94, pp. 8292-8299 (1997).

23. Takeuchi, K., Fujioka, Y., Kawasaki, Y., and Shirayama, Y., "Impacts of High Concentration of $\mathrm{CO}_{2}$ on Marine Organisms: a Modification of $\mathrm{CO}_{2}$ Ocean Sequestration," Energy Conversion \& Management, Vol. 38, pp. S337-S341 (1997).

24. Walther, G.-R., Post, E., Convey, E., Menzel, A., Parmesan, C., Beebee, T.J.C., Fromentin, J.-M., HoeghGuldberg, O., and Bairlein, F., "Ecological Responses to Recent Climate Change," Nature, Vol. 416, pp. 389-395 (2002). 